\title{
The valuation and financial management of (nano-)technology in relation to sustainable growth
}

\author{
S. Čiháková Aguilar, M. Dubová \& E. Mucsková \\ Institute of Novel Technologies and Applied Informatics, \\ Technical University of Liberec, Czech Republic
}

\begin{abstract}
This article is concerned with the valuation and financial management of new technologies and R\&D projects in relation to sustainable growth. It introduces a general economic model that answers critical questions on how to analyze technology initiatives and forecast their future value. The aim of this model is to provide a practical decision-making tool that reduces the total costs of $R \& D$ projects, to help financial managers, scientists, and engineers make better and comparable decisions within the financial management of technology by a user-friendly tool, to enable its users to make and see all relevant cash flows associated with R\&D projects more transparent. The further objective of this article is to demonstrate the practical usage of this economic model on the valuation of a modern and original technology (nano-fibrous carrier) for wastewater treatment, applying tailor-made microorganisms with the ability to create natural biofilm. The nanotechnology was developed at the Technical University of Liberec - Faculty of Mechatronics, Informatics and Interdisciplinary Studies in cooperation with the Faculty of Textile Engineering; The Institute of Chemical Technology Prague (ICT, VŠCHT in Czech) Department of Fermentation Chemistry and Bioengineering; and the company AQUATEST in the Czech Republic.
\end{abstract}

Keywords: valuation and financial management, general economic model, $R \& D$ projects, technology (nano-fibrous carrier) for wastewater treatment, sustainable growth. 


\section{Introduction}

The Technical University in Liberec (TUL) has developed the unique technology "Nanospider TM", which enables the industrial production of unwoven fabric created by fibers with a diameter from tens to hundreds of nanometers. TUL started to cooperate with the company "Elmarco" and developed "Nanospider" a machine that is able to produce nanofiber for functional fabric. Their broad applications can be observed not only in the automobile industry, machinery, and the construction and chemical industries, but also in branches such as health care, electronics, energetics, military and the cosmic industry, etc. Another application of nanotechnology is the protection of the environment, specifically the branch of wastewater treatment (WWT). There are different ways to clean industrial wastewater. The selection of the appropriate treatment method depends on the contaminants, the composition of the water body and the total economic operation.

The aim of this article is to contribute to the discussion on economic scientific projects from the perspective of the valuation and financial management of progressive technologies regarding the sustainable growth of companies and the global economy. It describes in a deductive form the specific case of the analytical tool of the developed technology that financial managers and also scientists and engineers can apply for decision making towards their projects on new technologies. A relevant application of this work might be communication and understanding among scientists and financial managers.

\section{Valuation of new technologies}

The process of valuation has been for a long time a subject of interest. The subject of valuation can be material things, such as houses and jewels, but also more abstract ones, such as new technologies. The term valuation refers to the monetary roles of particular goods [2]. There are three methodologies traditionally used for the determination of the value of property: market approach, income approach and cost approach [9]. All of these traditional ways of valuation can help one to establish the economic and physical characteristics of certain property. Each of these methodologies can present some variations due to the diversity of valuators, which might adapt the results according to the final application of the valuation.

Two different groups work during the process of transformation of research into a new technology: scientists and financial managers. The existence of different backgrounds is one of the main reasons for the difficulty in communication among these groups. The valuation of technologies can serve as a bridge that can bring together the ideas towards an appropriate decision making process related to new technology $[1,2]$.

The valuation of technologies is a complex task and can be applied just within the context of a specific business situation or specific company. Some of the methods are listed below. 


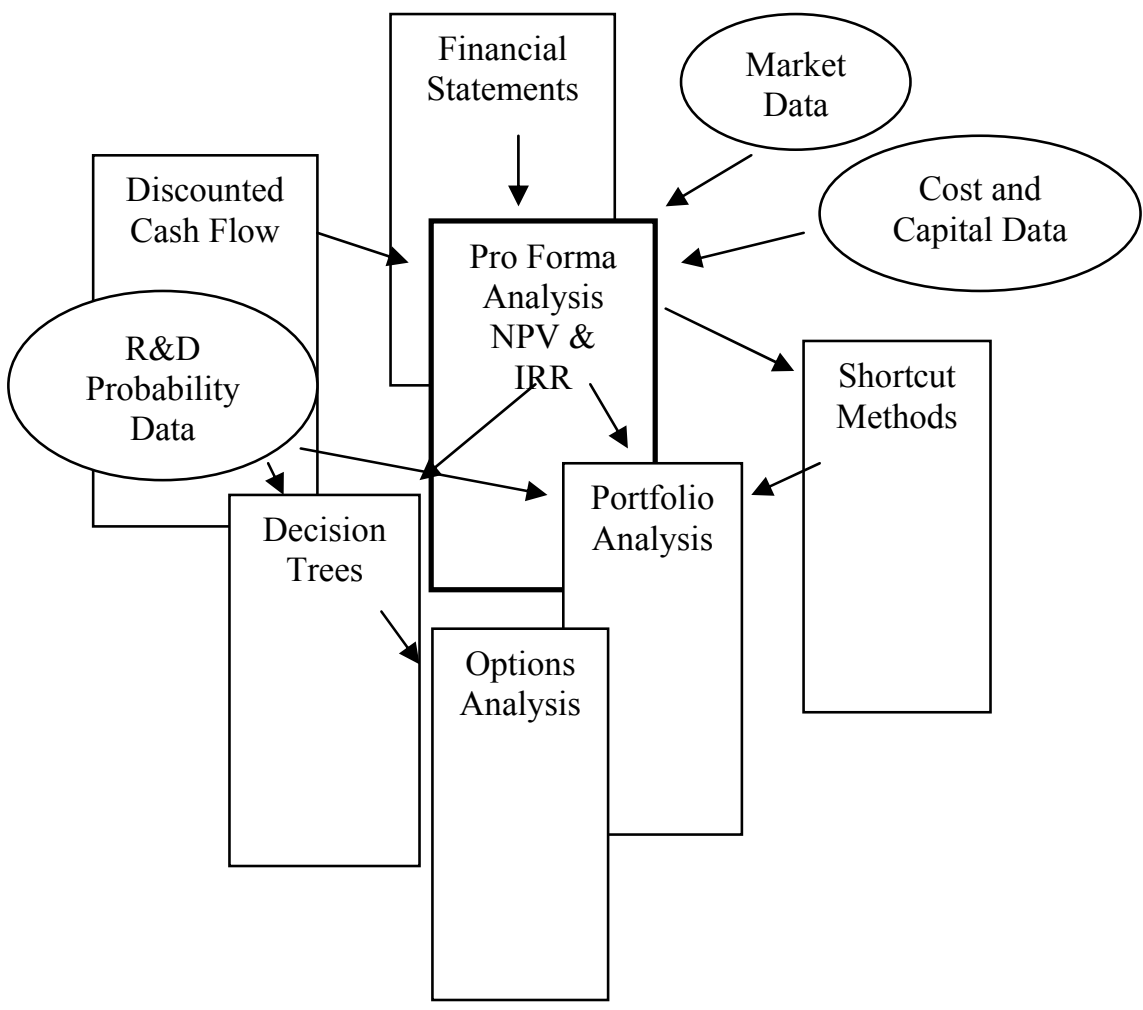

Figure 1: Technology valuation roadmap [2].

- Cost analysis

- Pro forma analysis NPV \& IRR

- Net present value and analysis of internal rate of return

- Sensitivity analysis

- Decision trees

- Risk analysis

- Monte Carlo methods

- Portfolio analysis

- Shortcut methods [2]

Figure 1 provides a road map to the approach to the valuation of technology. Input data are shown as ovals, whereas methods are shown as rectangles.

\section{Valuation of technologies for wastewater treatment}

A new technology using nanofiber for wastewater treatment has been developed and tested within the research and development project "Advanced Remediation Technologies and Processes Center". The research is in charge of several scientific teams of different branches (chemistry, natural sciences, engineering, 
mathematic modeling). At the present time, an economic valuation of the technology is also taking place in the project, which is based on the comparison of the current applied technology using AnoxKaldnes biofilm by a company, the name of which is not mentioned in this work due to the existence of sensitive data. (For the purposes of this article, we called it "Company A".) Section 3.2 describes the technology used by Company A and Section 3.3 describes the nanotechnology.

Modern methods of valuation and corporate financial management can be applied for the valuation of technologies for wastewater treatment. The information provided by the experts on technology is translated by the economic team into valuation models containing detailed cost analyses describing the wastewater treatment technology.

\subsection{Chemical/biological wastewater treatment plant}

The reconstructed industrial chemical/biological wastewater treatment plant of Company A is determined at the present time for:

- Decontamination of wastewater containing cyanide and organic materials for residual waters originated in technological processes for the production of diphenylguanidine (DPG) and acetone cyanohydrin $(\mathrm{ACH})$

- Reduction of the contents of cyanide in wastewater from the production of diphenylguanidine

Implementation of biological treatment of wastewater was the reason for the innovation of production of the plant, which might lead to an increase on production. Consequently, the plant management decided to combine the innovation of production with the construction of the new water treatment plant. The whole investment deals with modernization of chlorocyan and diphenylguanidine (DPG) production with the aim of increasing process safety, production capacity, and continuity of chlorocyan production. The environmental safety of production is secured by non-waste combined physicochemical and biological treatment of wastewater in the newly established wastewater treatment plant. Diphenylguanidine is a highly sophisticated component used in the rubber industry (tire production) costing approx. 2500 EUR per ton. The reconstruction of the production unit enables the plant to increase production twofold (from $900 \mathrm{t} / \mathrm{year}$ to almost $2000 \mathrm{t} / \mathrm{year}$ ) together with the implementation of a safety system for wastewater treatment. Implementation of new water treatment technology enables the plant to fulfill the requirements of the Integrated Pollution Prevention and Control (IPPC) Act, as well as the requirements of the new Water and Waste Acts.

The company produces about $20 \%$ of the worldwide production of DPG. The DPG market is stable and has an annual increase of approx. 5\%. The prognoses revealed the same increase in demand of DPG in the coming years. Investment into modernizing the production and improvement of the wastewater treatment create the possibility for sustainable development of the company, maintain existing jobs, and bring the possibility for new jobs in the coming years [6]. 


\subsection{Technology using AnoxKaldnes biofilm}

With the technology, AnoxKaldnes can use plastic carriers to take up to $70 \%$ of the volume of the water deposit; the carriers are designed to be suspended on water and therefore to enable a more protected surface for the growth of biofilm and optimal conditions for the development of bacteria.

This technology can be applied for industrial and for municipal wastewater treatment. One of the greatest advantages is the high flexibility of the process, which enables to combine the system in different forms with the classical activation process depending on how appropriate it might be for the effective dissolution of contaminants. This technology reports a stable high efficiency of elimination of pollutants from 80 to $99 \%$. Another interesting fact is its low production of sediments, which also helps to decrease costs.

The technology uses biofilm growing in the internal surface of the carriers' structure. These are plastic "wheels" with different structures, depending on the type. The form is determinant for the demands on transport of substracts and oxygen to the microorganisms.

The diameter of the carrier $\mathrm{K} 3$ is $25 \mathrm{~mm}$, the total usable surface is 600 $\mathrm{m} 2 / \mathrm{m} 3$, from which the internal protected surface is $500 \mathrm{~m} 2 / \mathrm{m} 3$. The density $1000 \mathrm{~kg} / \mathrm{m} 3$ of the applied carrier material ensures that the density of the biocomplex gets about the level of wastewater for the growth of biomass on the carrier. For the maintenance of their suspension is important to release minimum energy [8].

\subsection{Polypropylene, polyurethane and nano-fibrous carriers}

This technology was created by the Department of Nonwoven Textiles of the Technical University in Liberec and developed by the Center for Advanced Technologies and Processes for wastewater treatment. It represents a more flexible polymeric carrier than the one used by AnoxKaldnes and have the following advantages:

- An effective surface, which is supported by a nano-fibrous film with a highly specific protected surface. This allows bacteria high adhesivity (enables their immobilization) mainly at the first stages of the carrier's surface colonization.

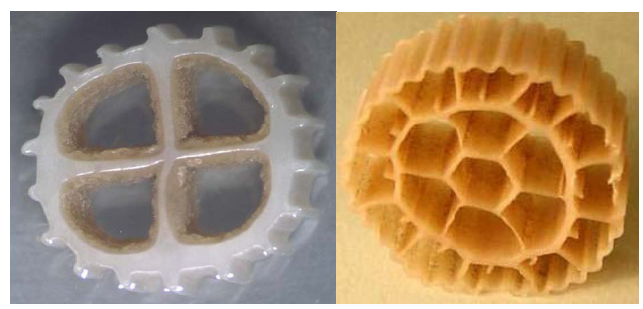

Figure 2: Technology AnoxKaldnes, K1 industrial, K3 municipal [5]. 

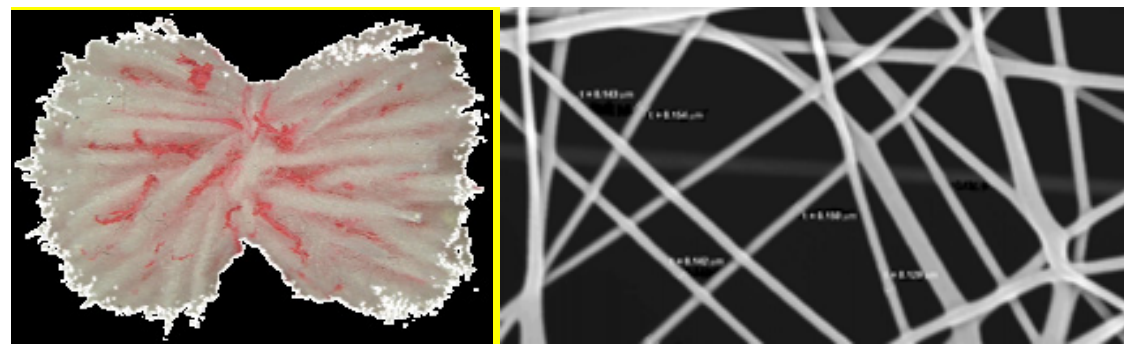

Figure 3: Nano-fibrous carrier, detail of the nano-fibrous layer (SEM) $[4,8]$.

- A big advantage of this technology is the possibility of combination of different polymers in order to set the carriers density (from $900 \mathrm{~kg} / \mathrm{m} 3$ for PP until $1200 \mathrm{~kg} / \mathrm{m} 3$ for PU).

- Other advantages of the nano-fibrous carriers are durability, easy formation, resistance against chemicals, low thermal characteristics and resistance against abrasion (mainly with nanofilm).

- A greater selection of the structure and design of the carriers, which minimizes e.g. the cost of mixtures.

- A significant advantage of this technology is the application of biofilm growing in the internal surface of the carriers' structure. With this design, bacteria are better protected from the toxic influence of the surrounding environment and are determinant for the demands on transport of substracts and oxygen to the microorganisms [8].

From the economic point of view, these carriers have the following advantages:

- Higher efficiency for the elimination of contamination (results from laboratory tests).

- The cleaning process becomes renewable in a faster way in case of a plant failure. This leads also to the following effects:

a) Shorter shut-down. Serious failures on wastewater treatment plants, which can appear 1-2 times a year, represent a reduction in the production of about $8-16 \%$ (1-2 months). The process can be restarted up to 2 times faster with the application of nano-fibrous carriers compared with the technology using AnoxKaldnes (4-8\% reduction of production a year).

b) Higher stability of the cleaning process and, therefore, fewer ecological related fines.

\section{Structure of the economic model for wastewater treatment technology for the Czech Republic}

The suggested model for the valuation of wastewater treatment technology is a result of the review of theoretical and technological issues, the information from the scientific groups and the principles of corporate financial management as 
described in [1-3, 9]. The MS Excel processor might be used for its elaboration. Thanks to the application of the software support, it is possible to simulate trends of values in case of changes in relevant variables. The model of valuation of the technology of wastewater treatment can be useful for more efficient decisionmaking processes.

The authors suggested the following structure of the general economic model for the valuation of wastewater treatment technologies:

- Cost model wastewater treatment technology

- Depreciation model of wastewater treatment

- Cash flow model of wastewater treatment

- Sensitivity analysis

\subsection{Cost model for the wastewater treatment technology}

The model can be used as a general cost model, that can serve for the calculation and estimation of the total costs before the first operations of the plant and also for the costs during the time the plant is running. The model was developed with the support of the software MS Excel, which enables easier up-dating and simulation.

The cost analysis was created for the valuation of the two types of technologies mentioned in this article (AnoxKaldnes and Nano-fibrous Carriers) taking as example the operations of company A. There are two important categories of costs for the wastewater treatment technology: A) Startup costs and expenditures of the wastewater treatment plant, and B) Operation costs during 1 year.

The first category can be divided as follows:

1. Research costs including scientific testing

2. Project working

3. Construction

4. Carrier for the wastewater treatment technology

a) Nano-fibrous carrier

b) AnoxKaldnes "wheels"

Research costs include costs for laboratory tests -external services, research staff payroll costs, laboratory materials, travel costs.

After the primary research and testing, there is time to put in practice the concrete technology, where there is necessary to prepare the required documentation. In this phase it is important to prepare:

1. Pre-project working (EIA, design, pilot experiments).

2. Project for the construction permission, which needs: building project, electrical installation project, project for the wastewater treatment technology, project for the measurement of regulation, project for fire safety, project administration costs, and travel costs.

3. An important part of the project working is the operative project, which describes in a detailed form all these documents for the construction permission. 
After obtaining the construction permission for the wastewater treatment plant, there is time to start building. The construction includes the following costs: building-site arrangement, base plate, tank construction, construction of a local laboratory station, wastewater neutralization, sediments filtration, biological deintoxication, aeration system, measurement of the regulation, coupling, building and technical control. An important part of the plant is the central technical area or machine room.

Before the plant starts to operate it is necessary to invest on employee training and some provision.

The cost analysis for both technologies differs on the efficiency level of the specific type of carrier (Nano-fibrous and AnoxKaldnes).

The technology applying the nano-fibrous carrier is at the phase of testing and research, so it is not possible to know its market price. It was necessary to make a calculation of this price based on information provided by members of the scientific group of the Department of Non-woven Textiles from the Faculty of Textiles, Technical University in Liberec. The calculation considered:

- Price of textile machine - 30-50 mil. CZK,

- Estimated operating lifetime - approx. 20 years,

- Estimated costs for $1000 \mathrm{~m}$ of nanofiber - about $48 \mathrm{CZK}$ under industrial conditions

- Number of machines -2:

a) One extension line produces layers of nano-fibrous yarn and wraps the yarn. The machine has winding and unwinding options. Production of the machine: about $200 \mathrm{~m}$ of yarn per minute. (According to laboratory results, this can be improved).

b) The second extension line produces the carriers from the layers of yarn. Machine production: 6-15 carriers per minute from one knitting unit. One machine can have 5-10 knitting units. (According to laboratory results, this can be improved).

The price the nano-fibrous carrier was estimated to approx. $15 \mathrm{CZK}$ per liter (the market price of AnoxKaldnes "wheels" is approx. $13 \mathrm{CZK}$ per liter). The price was estimated through the information above, and also estimations from direct and indirect inputs to the production process of nano-yarn and its consequent nano-fibrous carrier.

Operation costs for one year of operation of the plant are: employee costs for maintenance, cleaned water limits control and monitoring, calibration costs, operation service, provision, insurance, overhead and final technical control for the pilot operations.

Group of data that are applied for further calculations of the valuation of technology:

- Investments (capital outlay).

- Startup non-capital costs (expenditure).

- Annual operation costs (expenditures) without depreciation [7]. 


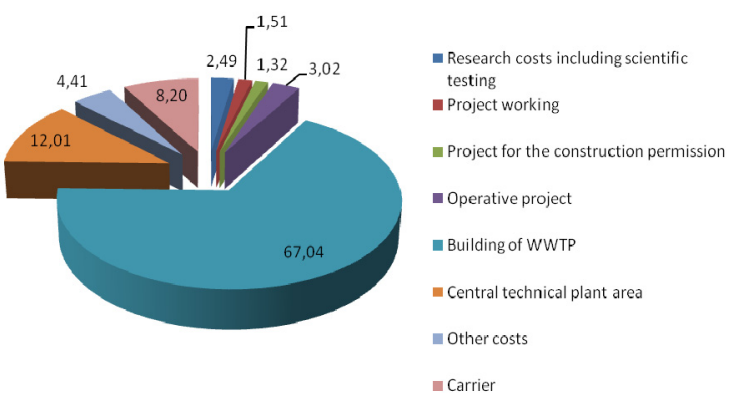

a)
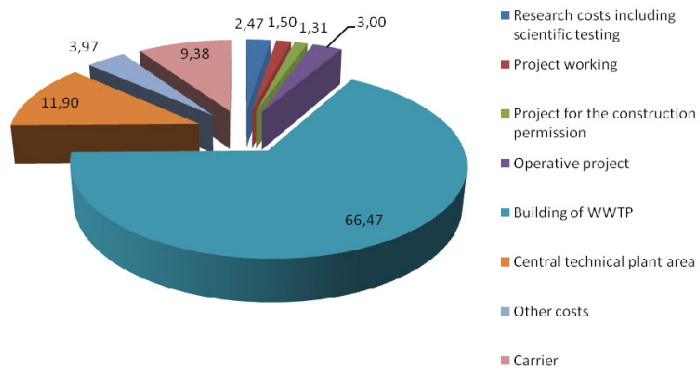

b)

Figure 4: Cost analysis (\%): a) AnoxKaldnes, b) nano-fibrous carrier.

The graphs below represent the relative costs (startup costs and expenditures of the wastewater treatment plant) for both technologies.

\subsection{Depreciation model}

Depreciation reduces the value of an asset as a result of usage, age, or obsolescence. Most assets lose their value over time (in other words, they depreciate), and must be replaced once the end of their useful life is reached. There are several accounting methods that are used in order to write off an asset's depreciation cost over the period of its useful life. Because it is a non-cash expense, depreciation lowers the company's reported earnings while increasing free cash flow. Depreciation is one of the most important elements of the operation costs and therefore, one of the most important input data to the Cash Flow Model. In order to obtain the real cash flow for the investment in technology, it is necessary to include depreciation estimations in the profit calculations of the wastewater treatment plant. 
There are two types of depreciation: book and tax depreciation. Book depreciation is calculated in different forms by each company. For purposes of this work, we decided to apply tax depreciation due to its general validity for companies in the Czech Republic.

Our model calculates automatically the depreciation and residual prices for each year of the plant's lifetime and it's based on the Czech income tax law.

\subsection{Cash Flow Model}

Our aim is to translate the Cash Flow Model into a MS Excel Format, like the models mentioned above. At the present time, we have prepared the main design. The final result will be part of the diploma work of one of our students.

The main part of the economic tools for the valuation of wastewater treatment plants will be the Cash Flow Model, which should present as many factors as possible, which influence the cash flow related to specific technologies in a period of time of 31 years (one year of building and 30 years operation lifetime). Examples of factors will be: development of prices for the market of DPG, company's capital structure development, time value money, expected inflation rates, tax policy trends and the financial market situation.

We will also include considerations about the trends in market price of DPG, discounting rate, inflation rates with tax rates for corporations (for the year 2010 the tax rate is 19\%) according to the income taxes law (586/1992). The user will have the choice to include the plant's investment amount for each year of its construction and also the required investment recovery time. The user also will have the opportunity to choose if the project will be financed only with own capital or also with foreign capital-debts. After the introduction of these input parameters, the application will calculate automatically the amount of cash flow for each year of the lifetime operation of the wastewater treatment plant.

There will be considered also automatic calculations of net present value, cost recovery time according to the time value of money and internal rate of return. Their principle is the discounting of future cash flow, which will enable the calculation of the net present value and also the comparison among these results.

Net present value can be defined as the difference between discounted cash incoming flows from investments and discounted capital outlay for each year:

$$
\check{C} S H=\sum_{n=1}^{N} P_{n} \frac{1}{(1+k)^{n+T}}-\sum_{t=1}^{T} K_{t} \frac{1}{(1+k)^{t}}
$$

where:

$\check{\mathrm{CSH}}$ is the net present value,

$\mathrm{T}$ is the time of building the plant,

$\mathrm{t}$ is each period of time for the building,

$\mathrm{P}_{\mathrm{n}} \quad$ is cash income for each period of the operation lifetime,

$\mathrm{n} \quad$ is each period of time of the operation lifetime,

$\mathrm{K}$ is the capital outlay, 
$\mathrm{k} \quad$ is the discounting rate $=\frac{\mathrm{kv} \%}{100}$,

$\mathrm{N}$ is the operation lifetime.

The results obtained with the application of the net present value for the valuation of efficiency of technologies can be interpreted in the following ways:

- Net present value of the investment in technology is greater than 0 . This result means that the company should accept the technology, because it ensures the desired rentability. This is a technology that adds value to the firm.

- Net present value of the investment in technology is less than 0 . This investment should not be accepted by the company.

- Net present value of the investment in technology equals 0 . This investment neither adds value to the company nor loses it. It is up to the company if the investment will be accepted [3].

The internal rate of return (IRR) presents another dynamic method for the valuation of technology efficiency. It is the discounting rate $\mathrm{k}$, at which the present value of cash inflow from the technology for wastewater treatment equals the present capital outlay. It can be also defined as the discounting rate at which net present value equals zero. It can be represented as follows:

$$
\sum_{n=1}^{N} P_{n} \frac{1}{(1+k)^{n+T}}=\sum_{t=1}^{T} K \frac{1}{(1+k)^{t}}
$$

An investment is considered acceptable if its internal rate of return (IRR) is greater than an established minimum acceptable rate of return or cost of capital. An investment whose IRR exceeds its cost of capital adds value for the company (i.e., it is profitable). If the IRR equals the cost of capital, the company has to look at other criteria for the decision of investment in specific technology for wastewater treatment.

\subsection{Sensitivity analysis}

A part of the economic analysis has to be the sensitivity analysis, which takes into account the influence of some important variables that are expressed as relative deviation of the values of the project. For the particular case of wastewater treatment, the authors consider to test mainly the following variables: price of applied carrier, time of renewal of the cleaning process for each carrier, price of production of the company, etc.

The criteria of capital project analysis mentioned in the previous chapter of this article give a static picture of the likely future out-turn of the technology. In many business situations, it is desirable to generate a more complete and realistic impression of what may happen to for instance NPV in conditions of uncertainty. Net present value calculations rely on the appraiser making assumptions about some crucial variables.

Answering these questions can help the sensitivity analysis, which is an integrant of this model. The sensitivity analysis examines the degree to which the 
viability of the technology changes, as measured by NPV, as the assumed values of the key variables are altered. In this part of the model, the user can ask for instance: if the purchase price of DPG was raised by 10 percent, by what percent would NPV increase? By carrying out a series of calculations, the model helps to build up a picture of the nature of the risks facing the technology. Through the sensitivity analysis, the model can identify the extent to which variables may change before a negative NPV is produced.

Sensitivity analysis has the following advantages:

- Information for decision-making: at the very least it allows the decisionmakers to be more informed about project sensitivities, to know the room they have for judgmental error and to decide whether they are prepared to accept the risks.

- To direct search: if sensitivity analysis points to some variables being more crucial than others, then search time and money can be concentrated.

- To make contingency plans: during the implementation phase of the investment process, the original sensitivity analysis can be used to highlight those factors that have the greatest impact on NPV. Then these parameters can be monitored for deviation from projected values. The management team can draw on contingency plans if the key parameters differ significantly from the estimates [1].

\section{Conclusions}

The above-described economic tool is intended to be applied for the valuation of technologies for wastewater treatment plants and also for the analysis of their economic issues. The work presented in this article is still not the final result of our project. The authors plan to extend this work on the graphical aspect (graphs for relative costs, etc.), and also on the financial side through financial reports such as income statement, balance sheet and cash flow analysis as well as further calculations with the use of the Monte Carlo method.

In future works we intend to incorporate the valuation of more technologies dealing with biomass carriers, which are being subject of research of our teams.

This article was created under the state subsidy of the Czech Republic within the research and development project "Advanced Remediation Technologies and Processes Center" 1M0554 - Programme of Research Centers supported by Ministry of Education.

\section{References}

[1] Arnold, G. Corporate Financial Management, 3rd. ed. UK: Pearson Education Limited, 2005. 1200 s. ISBN 0-273-68726-3

[2] Boer, F.P. Oceňování technologií, 1. vyd. Brno: Zooner Press, s.r.o., 2007. ISBN 978-80-86815-66-4

[3] Brealey, R., A., Myers, S., C. Principles of Corporate Finance, New York: McGraw-Hill Companies, Inc., 1996. ISBN 0-07-114053-0 
[4] Galerie materiálů. TUL, Fakulta textilní, Katedra netkaných textilií. Available from www: http://www.ft.tul.cz/depart/knt/nove/dokumenty/ katedra/download/materialy_knt.pdf

[5] Homepage of the technology AnoxKaldnes, http://www.anoxkaldnes.com/ Eng/c1prodc1/mbbr.htm,http://www.veoliawaterst.com $/ \mathrm{mbbr} / \mathrm{cz} /$ application s.htm

[6] Interní materiály blíže nespecifikované firmy

[7] Král, B. a kol. Manažerské účetnictví, Praha: Management Press, 2006. ISBN 80-7261-141-0

[8] Křiklavová, L. Technologický návrh biofilmového reaktoru $s$ nanovlákenným nosičem pro čištěni průmyslových odpadnich vod-Diploma work, TUL, Fakulta mechatroniky, informatiky a mezioborových studií, 2009.

[9] Mařík, M., Maříková, P. Moderní metody hodnocení výkonnosti a oceňování podniku, Praha: Ekopress, 2001, 70s. ISBN 80-86119-36-X 